Meta

Journal des traducteurs

Translators' Journal

\title{
Harry Potter for Children, Teenagers and Adults
}

\section{Lia Wyler}

Volume 48, numéro 1-2, mai 2003

Traduction pour les enfants

Translation for children

URI : https://id.erudit.org/iderudit/006954ar

DOI : https://doi.org/10.7202/006954ar

Aller au sommaire du numéro

Éditeur(s)

Les Presses de l'Université de Montréal

ISSN

0026-0452 (imprimé)

1492-1421 (numérique)

Découvrir la revue

Citer cet article

Wyler, L. (2003). Harry Potter for Children, Teenagers and Adults. Meta, 48(1-2), 5-14. https://doi.org/10.7202/006954ar

\section{Résumé de l'article}

Une traductrice professionnelle raconte son expérience de traduction en portugais du Brésil de la série Harry Porter, de J. K. Rowling, avec des commentaires sur les conditions et les prémisses de son travail ainsi que les marques culturelles britanniques qui ont été conservées ou rayées pour donner une véracité à un monde magique et rendre le texte plus fluide pour les lecteurs de 9 à 12 ans. Elle traite aussi, brièvement, de l'achat et de la réception de l'oeuvre, de son succès inattendu parmi les adolescents et les adultes, de la couverture des médias et de la visibilité exceptionnelle ainsi obtenue.
Ce document est protégé par la loi sur le droit d'auteur. L’utilisation des services d'Érudit (y compris la reproduction) est assujettie à sa politique d'utilisation que vous pouvez consulter en ligne.

https://apropos.erudit.org/fr/usagers/politique-dutilisation/ 


\title{
Harry Potter for Children, Teenagers and Adults
}

\author{
LIA WYLER \\ Professional Translator, Rio, Brazil \\ lia.wyler@terra.com.br
}

\begin{abstract}
RÉSUMÉ
Une traductrice professionnelle raconte son expérience de traduction en portugais du Brésil de la série Harry Porter, de J. K. Rowling, avec des commentaires sur les conditions et les prémisses de son travail ainsi que les marques culturelles britanniques qui ont été conservées ou rayées pour donner une véracité à un monde magique et rendre le texte plus fluide pour les lecteurs de 9 à 12 ans. Elle traite aussi, brièvement, de l'achat et de la réception de l'œuvre, de son succès inattendu parmi les adolescents et les adultes, de la couverture des médias et de la visibilité exceptionnelle ainsi obtenue.
\end{abstract}

\section{ABSTRACT}

A professional literary translator recounts her experience in rendering J.K. Rowling's Harry Potter series into Brazilian Portuguese in regard to working conditions and premises, British cultural marks maintained to preserve foreignness or erased for the sake of fluency and the verisimilitude of a magical world for children between nine and twelve years of age. The purchase and reception of the book, which enjoyed unexpected success, among older teenagers and adults, media coverage, and the unusual visibility attained by the translator, are also briefly discussed.

\section{MOTS-CLÉS/KEYWORDS}

Brazil, Harry Potter, re-creation, cultural marks, translation for children

The point of view expressed in this essay is that of a professional literary translator, who works with different authors and different genres for different publishing houses to short deadlines.

In consequence - and this is generally the case in Brazil - I do not choose the foreign texts I am going to work with but rather am chosen by the publishers to translate certain authors and genres consecutively. So I may translate, as I have done throughout my career, Henry Miller, Muriel Spark, Joyce Carol Oates, Bashevis Singer, Annie Proulx, Saul Bellow, Gore Vidal and John Updike followed by Tom Wolfe, Stephen King, Nobel Prize science laureates, and more recently Sylvia Plath, Janell Cannon, Paula Danzinger, Julia Alvarez, Michael Hoye and J.K. Rowling for children.

To cope with this wide variety of language and themes, translators working with mass literature must stay abreast of the latest world news as well as devote time to field, Internet and library research, in order to assimilate changes and neologisms in both source and target languages. Imported mass literature represents eighty percent of the Brazilian fiction market and short deadlines are conditioned by global marketing policies agreed on at the time the copyright for successful foreign books are bought.

A short deadline for a professional translator is to translate a 348-page book like Harry Potter and the Prisoner of Azkaban in 119 days along with two revisions and 
biweekly discussions with the publisher's proofreader, as a necessary precaution against mutilation. Though Brazilian copyright laws forbid changes in translators' texts without their knowledge and approval it happens all the time. Mutilation may result from both a short deadline and the translator's need to take on a new book immediately after finishing the last one, as well as lack of interest in rereading the text before publication. Alternatively, it may occur due to the proofreader's short deadlines, long working hours, and insufficient knowledge of source or target languages.

\section{Purchase and reception of Harry Potter}

The editorial manager of Rocco, a medium-sized publishing house, acquired the copyright to translate Harry Potter into Brazilian Portuguese in December 1998. At the time it was neither a 7-book series nor a worldwide bestseller, but an interesting adventure for 9 to 12-year-olds, with all the ingredients of other well-known English children's classics, minus the illustrations. Another apparent difference: though permeated by folklore and mythological archetypes that anyone can easily identify with, Harry Potter is a serialized fairy tale written in contemporary language and set in our time. After the success of Rowling's first book in the United Kingdom in 1997, she received a grant from the Scottish Arts Council that enabled her to write the sequel. These were the main reasons for Rocco's initial interest in her work. Next she became known in a large number of countries, won three consecutive Nestle Smarties Awards (1999, 2000 and 2001) and took Warner Bros. as her business partner.

In 1998, I had received an award for the translation of Sylvia Plath's The-doesn'tmatter-suit, another Rocco title. So my name was quite naturally suggested for the translations of both Harry Potter and the Philosopher's Stone and Harry Potter and the Chamber of Secrets within the shortest time possible. However, they were not published until April and August 2000, respectively, when a huge marketing machine had been set in action for the sale of seven books and various Harry Potter products for children all over the world.

By 2001, when the first film of the series was shown in Brazil, my four translations had sold a million copies, so Warner Bros. felt compelled to pirate them for their film, video and DVD. Harry Potter and the Philosopher's Stone in visual media renewed the interest of the audience in the books, raising sales to one and a half million copies.

From the publication of the first volume, Rocco received a continuous stream of mail that averaged eight hundred messages per month in the first and second years, addressed both to the publisher and, unusually enough, to the translator. This mail came in the form of letters and Internet messages from children, teenagers and parents, mostly praising the colloquial language used in the dialogues, although some parents criticized this very acidly.

Two pieces of criticism were particularly remarkable: one reader calculated the translator's work pace for the fourth book (636 pages) at one page per five minutes, twelve per hour, ninety-six per day, allowing ten additional days for revision and a month and 10 days for publisher's proofreading and printing. He finished off by accusing the publisher of holding the book back to raise expectations and boost sales.

The second message, sent to an important newspaper by a 10-year-old bilingual child produced a colossal controversy in the media. The child questioned my trans- 
lation of "Muggle" as "trouxa," a slang word for fool, one meaning among many attributed to the word which the author herself confirmed a few months later before a British court of law. The newspaper interviewed their translator, linguists, schoolteachers and university professors and finally telephoned me to ask what I had to say on the matter. Other newspapers, weeklies and TV stations proceeded to jump on the bandwagon. The dissonance finally began to die down after the publication of an article signed by a respected literary authority approving of my choices. Several translators also wrote indignant letters questioning the newspaper's expertise and intentions.

Some members of the local section of the International Board on Books for Young Children, acknowledged as good writers in Brazil and abroad, complained publicly that no worthy Brazilian book had ever received such press and that Rowling's books, full of linguistic clichés and well-known plots from British classics were nothing but a merchandising phenomenon. But reports from book stores and schools all over Brazil, even from Amazonian schools and libraries, said otherwise: there were waiting lists of children wanting to read about Harry Potter's adventures in translation. Even bilingual readers and students of English preferred to read Harry Potter in Portuguese; maybe they just wanted to become acquainted with the text to be able to discuss the adventures with their Brazilian friends.

As in many other countries, children and teenagers substituted TV with reading - and after reading Rowling's series many young adults felt inclined to take up Tolkien's trilogy, which they had never before cared to read. Even older adults began to feel curious about this unexpected turnaround and were themselves charmed by Rowling's storytelling.

It reminded them of a Brazilian collection from their own childhood, written by José Bento Monteiro Lobato, including his own translations, really adaptations of European classics, Peter Pan, D. Quijote, Alice in Wonderland, Robinson Crusoe, Pinocchio, Grimm's and Anderson's folk tales. Besides adapting these books, Lobato brought their characters closer to the Brazilian public by making them interact with his own characters in an idyllic space called Sitio do Picapau Amarelo ${ }^{1}$ and even in outer space. Continuously republished until the sixties, his works became a TV series, recently remade and now showing again on TV, circumstances which have carried the author's influence on children's and adolescent literature into the 21 st century.

Lobato's first book, published in 1921, began what is known as the literary phase of Brazilian literature for young readers, who until then had read original and translated books imported from Portugal. A menina do Narizinho arrebitado (The girl with a cute upturned nose - Narizinho, in Portuguese), prefiguring our Modernism, combined historical and contemporary themes with fantasy, explored linguistic possibilities to form or invent new words and introduced Brazilian colloquial language to literature.

\section{Dealing with cultural differences}

As soon as I had leafed through the first Harry Potter, it reminded me so much of Lobato that I felt the need to discuss premises for my work with Rocco's editorial manager. The book belongs to the long tradition of popular tales and has all of the elements first identified by Propp in his studies of the genre: natural dialogues, worthy 
deeds and rewards, verisimilitude, mythical oppositions, the prevalence of Good over Evil, fast pace, suspense. All this had to be rendered into fluent Portuguese while preserving British customs, humor, formality and their manifestations. In my translations I also intended to let the Brazilian reader perceive that Harry Potter was an Other, with body language, facial expressions, habits and institutions different from his own, but with very similar longings, fantasies and conflicts.

The marks of Potter's Otherness were in:

- the way in which he referred to people of a higher rank, status or position as Mr. and Mrs. followed by their surname. We use "Seu" for men and "Dona" for women or their titles, "Doutor," "Professor." In Brazil, any man with apparent status can be safely called "Doutor."

- the English "you" is translated into "você," "tu," "o senhor" or feminine and plural forms. So "You-Know-Who," the name of the villain, who together with Harry form the light/darkness dichotomy, changed according to circumstances into "Pronoun-SabeQuem." To my consternation, a proofreader carelessly altered them to "Você-SabeQuem"(a third person pronoun) in all cases.

- the school year divided into quarters in England is divided into semesters in our country and there are two or three exams per year;

- the term "detention," "detenção," no longer used outside of government military schools and the armed forces, was reinstated as a feature of English "private" schools;

- the exact translation for "to gape," "boquiabrir-se" in Portuguese, which had fallen into disuse, was also recovered;

- the custom of calling students by their surname, usual in England between teachers and students and among students who do not know one another particularly well is no longer practiced in Brazil, except in the armed forces, schools and professions of military origin, such as aviation;

- the habit of frowning, a facial expression repeatedly mentioned;

- the cups of tea children and adults drink constantly as opposed to our small cups of black coffee for adults only;

- the custom of sending boys and girls boys away to private schools at the age of ten; Brazilians live with their parents until they finish university and sometimes after it;

- the concept of blue or pure blood was used deprecatingly in Brazil in the last century and is now relatively unknown except in animal breeding, although "good blood" has recently become current slang for a trustworthy person;

Conventional and idiomatic expressions and cultural idioms (Tagnin: 1987) received close attention. Chapter titles were changed when they had a more restricted meaning in Portuguese. This was the case with "The Journey from Platform Nine and Three Quarters"(p.67, v.1). The polissemy a "quarter" enjoys in English is nonexistent in Portuguese. For us a "quarto" is either a bedroom or a fraction, something nine-year-olds are beginning to learn in Arithmetic. So a quarter became "a half," as the idea to be preserved was that of an invisible platform between 9 and 10. Hence, "O embarque na plataforma nove e meia."

\section{Re-creating Harry Potter's world}

As a second step I contacted Ms. Rowling, through her literary agent, to confirm whether she had chosen the names for their weird sound or for their composition. For instance Dumbledore (p.12, v.1), Hogwart's director, is an archaic name for the golden bumblebee that combines English and French, "bumble d'or." 
The agent informed me that his author collected odd names for both their sound and composition and that it was up to me to decide whether to translate them or not. However, as an afterthought he asked Rocco for a brief curriculum vitae and my translations for a long list of proper names - both approved by Ms. Rowling, who lived in Portugal for a couple of years and speaks Portuguese.

To recreate Harry's magical world, I coined over four hundred words and, according to a survey conducted by a researcher (Fernandes: 2001) working for a doctor's degree, in The Philosopher's Stone alone I carried out 130 shifts of the types described by Embleton (1991: 176). Fernandes also acknowledges that proper names are heavily loaded with cultural and semantic meaning and provide much of the humor in children's literature. He concludes that in children books the translator faces not only the usual problem of personal names in literature, but also the problem of how to retain their comic effects.

I was not aware though that there would be a second book until I had finished the translation of The Philosopher Stone, a fact that would certainly have influenced my reinvention of certain proper names. There was an endless collection of characters, animals and things with strange polysemous names that helped to build the atmosphere of charm, fantasy and humor in Rowling's books.

Discerning which names were real or fictitious, and what terms belonged where in order to give them plausible equivalents was a task that consumed much time, study and imagination.

My long glossaries include original and translated names according to the following criteria:

- Topological names that helped anchor the story somewhere in the United Kingdom were maintained. Examples: Bristol, London, Manchester, Kings Cross, London subway;

- Brand names for brooms were kept in English as, by analogy, foreign cars are sold under their original names. E.g.: Nimbus 2000 and Firebolt, among others;

- Quidditch terminology was completely reformulated after well-known games, as well as by consulting various dictionaries to find possible equivalents where sources were unknown. As the game is played with four balls it became "quadribol," "quadri," a common Latin suffix and "bol" as in "futebol": "Quaffle," "goles," a word borrowed both from a reddish color in heraldry and the onomatopoeic "quaff," swallowing drink in one "gole" or continuous "goles"; Golden Pome or Snitch, "pomo de ouro," is none other than the Greek mythological pome; Portuguese names for "goal posts," "goalkeeper," "chaser," respectively "balizas," "goleiro" and "artilheiro" are football terms; "seeker" became "apanhador," bludger, "balaço" and "beater," "batedor";

- English names for two or three outlandish folkloric beings that were difficult to identify had to be maintained. Grindyllow and Kappas for instance;

- Names of charms and hexes were in Latin and so remained or were corrected as in the case of "Relashio," really "Relaxo";

- All other names were translated, using the linguistic possibilities of suffixing, prefixing, combining up to three words, reinstating words that had fallen into disuse, or adopting regionalisms. Brazilian Portuguese has three official variants (not dialects); the Rio de Janeiro variant used finds less resistance from readers, as the city was the capital of the country from the 17 th to the 20th centuries.

Buckbeak, the hippogriff (p.88 v.30), for example, became "Bicuço," a word formed by analogy with "bucktoothed," "dentuço," combining the words for beak 
and the suffix "uço," indicating that the animal named has a prominent beak; but most translations were not so simple. For Crookshanks, a cat with arched hind legs, I found and used the word "bichento," a Northeastern regionalism for humans with bow legs which sounds very similar to "bichano" a noun that we also use for cats.

Some titles required more elaboration to find them acceptable equivalents. This is the case of "The Mirror of Erised" (p.143, v.1), the word "desire" was inverted and, accordingly, I used the same procedure to get "Ojesed." But the explanation about the mirror's function contains a double inversion that affects all the words and the sentence itself. "Erised stra eheu oyt ube cafru oyt on wohsi" which in plain English means "I show not your face but your heart's desire." In Portuguese it became "Oaça rocu esme ojesed osamo tso rueso rtso moan."

On the other hand, "Knight Bus," was pure invention. After some time I settled for Nôitibus Andante by combining the words for night, bus and errant as in knighterrant.

\section{Registers}

Since 1999, there has been heated public debate regarding a proposed bill, which would forbid the use of unnecessary English words in Government papers, institutions, and in our communications media. So I made a point not to reinforce those English/ American structures that are gradually replacing our own. In Portuguese, an adjective, for example, can be post-posed or preposed to a noun, in which case it acquires emotional connotations. Currently, many adjectives are being preposed inattentively through contamination.

Considering that the first Harry Potter book was written for children between 9 and 12 years of age in different levels of literacy, I avoided the temptation to employ an easy language. Instead, I tried to write an unambiguous and enjoyable text as one expects in mass fiction, especially in the case in point where there were no illustrations. Also I have consciously worked to expand the reader's vocabulary and help him visualize each scene, faithfully rendering details and variations in register. I also kept in mind that adults might read it aloud to younger children influenced by their older brothers and sisters interest, and, as happened in the United Kingdom, that older teenagers might become interested too.

For the narrator I adopted a mostly neutral register, formal or informal depending on the length of the sentence and implicit rules for writing a clear text. In Portuguese, register is indicated by choice of vocabulary and grammatical structures, and particularly by the position of personal object pronouns, which can be post-posed, interposed (rapidly becoming an archaism) or preposed to the verb. In addition, the verb ending indicates the personal subject pronoun, who is speaking and in what tense and mood - indicative, subjunctive or infinitive. The excerpt below shows these usages:

"He'd forgotten all about the people in cloaks until he passed a group of them next to the baker's. He eyed them angrily as he passed. He didn't know why, but they made him uneasy." (p.9, v.1)

"Esquecera (he/ past perfect) completamente as pessoas de capas até passar (infinitive) por um grupo delas próximo à padaria. Olhou-as (he/simple past/them) com raiva ao 
passar (infinitive). Não sabia (he/ imperfect past) o porquê, mas elas o (him) deixavam (they/ imperfect past) nervoso." (p.9, v.1)

The translation of colloquialisms and swear words current in dialogues between children was made possible not only by field research but also by the lucky circumstance of having a nine-year-old granddaughter who came twice a week to study at my home. Hearing that I was translating Harry Potter, a boy her age, she asked me to read it aloud. Instead, I recounted it orally, and in so doing, chapter-by-chapter, I became aware of certain obstacles to her full comprehension and appreciation of the text as well as the adequacy or inadequacy of children's colloquialisms and swear words.

Ms. Rowlings's text contains many texts in other styles and registers, such as school hymns, rhymed notices and samples of non-literary speech, which received careful translation to convey their peculiarities.

School hymns, for instance, one for each school year, are humorous self-deprecating pieces always "bellowed" (sic) by students. In Portuguese, the unit of rhythm in verse is the syllable, so I made an effort to translate it in eight-syllable verses, with the exception of the first two lines.

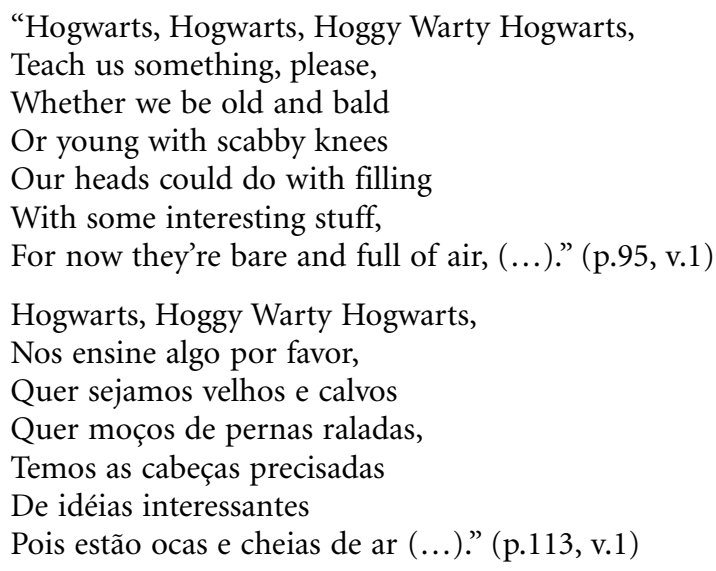

Newscast insertions, concise who-when-what-where-how required much adaptation to sound natural. In the sample below the names of U.K. cities were omitted; the verb tense was changed to present perfect as progressive forms are not considered good form in Brazilian Portuguese; the positions of downpour and rain were exchanged because "aguaceiro" cannot refer to stars, the word being composed of "água," "water" and the Latin suffix “-ariu," for intensity, among other things.

"Viewers as far apart as Kent, Yorkshire and Dundee have been phoning in to tell me that instead of the rain I promised yesterday, they've had a downpour of shooting stars!" (p.10, v.1)

"Ouvintes de todo o país têm telefonado para reclamar que em vez do aguaceiro que prometi para ontem, eles têm tido chuvas de estrelas!” (p.11, v.1)

Press articles follow the same basic demands as newscasts but allow for some extension depending on the space to be covered. As can be seen in the quote below, I maintained English surnames, but except for a handful, translated all other, literally 
or by phonetic approximation. Rôni is short for Ronald, a well-known name in Brazil; Lee, an unknown one, became Lino; Arthur lost its " $h$ "; Lucius, a Latin name, is Lúcio in Portuguese.

Giving native names to characters contributes to children's positive/negative identification with them, so this is the current procedure in translating for children. Young Brazilians who are not yet proficient in reading find English words difficult to pronounce. By contract, however, Harry Potter's name could not be altered, even if children had to struggle to pronounce an aspirated " $h$ " and retroflex " $r$ 's" - an ability found only in seven out of twenty-six states in Brazil.

Departments and sections in ministries and health and educational institutions support the verisimilitude of Harry's world, so the reader must understand what they mean, especially when they are so humorously absurd as St. Brutus Center for Incurable Criminal Boys. The same holds true for such book titles as Gadding with Ghouls (p.38 v.2). The quote below shows this work.

"ENQUIRY AT THE MINISTRY OF MAGIC

Arthur Weasley, Head of the Misuse of Muggle Artifacts Office, was today fined fifty Galleons for bewitching a Muggle car.

Mr. Lucius Malfoy, a governor of Hogwarts School of Witchcraft and Wizardry, where the enchanted car crashed earlier this year, called today for Mr. Weasley's resignation. (...)" (p.165, v.2)

\section{"INQUÉRITO NO MINISTÉRIO DA MAGIA}

Artur Weasley, Chefe da Seção de Controle do Mau Uso de Artefatos dos Trouxas, foi multado hoje em cinqüenta galeões, por enfeitiçar um carro dos trouxas.

O Sr. Lúcio Malfoy, membro do Conselho Diretor da Escola de Magia e Bruxaria de Hogwarts, onde o carro enfeitiçado bateu no início deste ano, exigiu hoje a demissão do Sr. Weasley. (...)" (p.189, v.2)

A second exception to the norm adopted for the translation of proper names was Hogwarts, Harry's school, given the impossibility of reproducing its connotations of hogs and warts. The plant, Croton capitatus in scientific jargon, is a plain "cróton" in Brazil.

In the series we read about a hilarious teenage sports commentator, Lino Jordan who presents Quidditch matches. This wizards game can be compared to a mix of other games and is played on brooms with four balls over a field delimited with side and end lines. Brazilians are mad about football and men usually watch the games on TV and go to stadiums with their young children, who are very familiar with the emotional and exaggerated speech of commentators as below.

'And she (Angelina)'s really belting along up there, a neat pass to Alicia Spinnet, a good find of Oliver Woods, last year only a reserve - back to Johnson and - no, Slytherin Captain Marcus Flint gains the Quaffle and off he goes - Flint flying like an eagle up there - he's going to $s c$ - no, stopped by an excellent move by Gryffindor keeper (...)" (p.137, v.1)

"E ela (Angelina) está realmente jogando com força total, um passe lindo para Alicia Spinnet, um grande achado de Olívio Wood, ano passado no time de reservas - de volta a Johnson e... não, Sonserina tomou a goles, o capitão da Sonserina, Marcos Flint, rouba a goles e se afasta veloz... Parece uma águia voando lá no alto ... ele vai mar... não, foi impedido por uma excelente intervenção do goleiro da Grifinória (...)” (p.162, v.1) 
Two of the four Hogwarts Houses, Gryffindor and Slytherin, are mentioned here and their compound nouns were divided for translation. I would have maintained the original names had I known there would be a sequel explaining their origins the surnames of the four founders of Hogwarts. "Grifinória," combines the words "grifo" (Gryffin) and "finória" (endowed with sagacity) and Sonserina combines the words "sonso" (sly) and "-ina," a Portuguese suffix meaning relation, similarity or nature."

This and other a posteriori explanations of the origin of names demanded unexpected work. In Quidditch through the ages the author explains how the wizards came to play with a Golden Snitch or Pome. Snitch was the name of a bird cruelly used as a ball in former days. So I had to rack my brains, trying to find a plausible name for an imaginary bird, "Pomorin," which later could be (or rather had been) shortened to "pomo."

Official letters are part of Harry's world and are written in the formal officialese found the world over. Here is a partial transcription of one letter reprimanding $M r$. Harry Potter:

Dear Mr. Potter,

We have received intelligence that a Hover Charm was used at your place of residence this evening at twelve minutes past nine.

As you know, underage wizards are not permitted to perform spell outside school, and further spell work on your part may lead to expulsion from said school (Dec4ree for the Reasonable Restriction of Underage Sorcery, 1875, Paragraph C)(...).” (p.21, v.2)

"Prezado Senhor Potter,

Fomos informados que um feitiço de levitação foi usado esta noite em seu local de residência às $9 \mathrm{~h} 12 \mathrm{~min}$.

Como o senhor sabe, bruxos de menor idade não têm permissão de realizar feitiços fora da escola e, a continuar esta prática, o senhor poderá ser expulso da referida escola (Decreto para restrição racional da prática de bruxaria por menores, 1875, parágrafo C)(...).” (p.24, v.2)

Very often in Portuguese, advertisements have to be totally re-created, reduced or extended in length, because one cannot simply aggregate nouns to become adjectives and form short new words as in English, while at other times it is possible to obtain the same results in length and impact, as below.

"The state-of-the-art racing broom sports a streamlined, superfine handle of ash, treated with a diamond-hard polish and hand-numbered with its own registration number. Each individually selected birch twig in the broomtail has been honed to aerodynamic perfection, giving the Firebolt unsurpassable balance and pinpoint precision. The Firebolt has an acceleration of 150-miles an hour in ten seconds and incorporates an unbreakable braking charm. Price on request." (p.43, v.3)

\section{FIREBOLT}

Fabricada com tecnologia de ponta, a Firebolt possui um cabo de freixo superfino e aerodinâmico, acabamento com resistência de diamante e número de registro entalhado na madeira. As cerdas da cauda, em lascas de bétula selecionadas à mão, foram afiladas para atingir perfeição aerodinâmica, dotando a Firebolt de equilíbrio insuperável e precisão absoluta. A Firebolt atinge $240 \mathrm{~km} / \mathrm{h}$ em dez segundos e possui um freio encantado de irrefreável ação. Cotação a pedido. (p.47, v.3) 
There are over twenty variations in oral and written speeches in Ms. Rowling's text, which include school letters and notices to students, letters and notes exchanged between adults and children, incantations and a fragment from a trial of wizards. Making everything sound Brazilian most certainly added to the young readers' enjoyment of the Harry Potter series with no adverse effects.

Many literary critics, religious leaders and educational authorities in the United States have criticized Ms. Rowling's work as being unliterary, unchristian and unworthy of use in schools. And the world media projects these declarations as if all Western and Eastern countries should follow suit.

As a translator of mass literature, I believe a work should be called "unliterary" when his/her author/ess aims to write a masterpiece and ends up publishing trash. Ms. Rowling apparently set out to write a thrilling, spell-binding adventure for children and has achieved her goal.

Also, differently from the US, in Brazil religion is a personal affair and animism is taken very naturally, Pentecostalism was the only religious denomination that bothered to alert its flock to the dangers of Harry Potter's "witchcraft."

As for the adoption of Ms. Rowling's works in schools, one should begin by asking: is mass literature written for educational purposes or entertainment? And curiously enough, they can be used to help in language learning. At my grandchild's Roman Catholic school the teachers decided to channel their second-graders' interest into reading The Philosopher's Stone as a class project. They discussed it, commented on colloquialisms and differences in registers and students were asked to write short fairy tales.

This idea to put the books to good use occurred to many teachers throughout Brazil and yielded an additional unsuspected benefit for translators: children were told that the author was a Scot and that the Portuguese version of Harry Potter was the work of a Brazilian translator.

\section{NOTES}

1. Sítio is a general term used for small to medium-sized farms but also rural properties used on weekends, where one usually grows vegetables and fruit. "Picapau amarelo" is a yellow woodpecker.

\section{REFERENCES}

Hermans, T. (1996): Translation's Other. Inaugural Lecture delivered at University College, London. Fernandes, L. (2001): The Translation of Personal Names in Harry Potter and the Philosopher's Stone: A brief Statistical Report. National Translators Forum, Belo Horizonte.

Propp, W. (1984): Morfologia do conto maravilhoso ("The Morphology of Wondrous Tales").

Trans. Jasna Paravich Sarhan. Rio de Janeiro: Forense Universitária.

Rowling, J.K. (1997): Harry Potter and the Philosopher's Stone. London: Bloomsbury.

Rowling, J.K. (1998): Harry Potter and the Secret Chamber. London: Bloomsbury.

Rowling, J.K. (1999): Harry Potter and the Prisoner of Azkaban. London: Bloomsbury.

Rowling, J.K. (2000): Harry Potter e a pedra filosofal. Trans. Lia Wyler. Rio de Janeiro: Rocco. Rowling, J.K. (2000): Harry Potter e a câmara secreta. Trans. Lia Wyler. Rio de Janeiro: Rocco. Rowling, J.K. (2000): Harry Potter and o prisioneiro de Azkaban. Trans. Lia Wyler. Rio de Janeiro: Rocco.

SANDroni, L. (1987): De Lobato a Bojunga ("From Lobato to Bojunga"). Rio de Janeiro. TAGnin, S.E.O. (1987): Levels of Conventionality and the Translator's Task. Doctoral Dissertation. São Paulo. 